\title{
Microcallus formation from maize protoplasts prepared from embryogenic callus
}

\author{
C.W. Imbrie-Milligan* and T.K. Hodges \\ Department of Botany and Plant Pathology, Purdue University, West Lafayette, IN 47907, USA
}

\begin{abstract}
Conditions have been developed that induce maize (Zea mays L.) protoplasts to re-synthesize cell walls and to initiate cell divisions. Two types of embryogenic maize callus were used as a source of protoplasts: a heterogeneous callus (Type I) derived from immature embryos after three weeks in culture, and a friable, rapidly growing callus (Type II) selected from portions of the Type I callus. Many variables in the growth conditions of the donor tissue (type of medium, transfer schedule, age of callus), protoplast isolation solutions $(\mathrm{pH}$, osmolarity, type and concentration of cell wall hydrolyzing enzymes, addition of polyamines) and conditions (amount of time in enzyme, amount of tissue per volume of enzyme incubation medium, agitation, preplasmolysis of source tissue, type of callus), and purification procedures (filtration and-or flotation), were found to affect both yield and viability of protoplasts (based upon fluorescein-diacetate staining). Our isolation procedure yielded high numbers of viable, uninucleated maize callus protoplasts which were densely cytoplasmic and varied in size from 20 to $50 \mu \mathrm{m}$ in diameter. Protoplasts plated in solid medium formed walls and divided several times. Of several gelling agents tested for protoplast propagation, only agarose resulted in protoplasts capable of sustained divisions leading to the formation of microcalli. Plating efficiency was established over a wide range of protoplast densities $\left(10^{3}-10^{7}\right.$ protoplasts $\left./ \mathrm{ml}\right)$. Highest plating efficiency $(25 \%)$ was obtained at $1 \cdot 10^{6}$ protoplasts $/ \mathrm{ml}$ ). The resulting microcalli grew to
\end{abstract}

\footnotetext{
* Present address: Department of Biological Chemistry, University of Michigan Medical School, M-4321/0606, $1500 \mathrm{E}$. Medical Center Drive, Ann Arbor, MI 48109-0606, USA

Abbreviations: $2,4-\mathrm{D}=2,4$-dichlorophenoxyacetic acid; $\mathrm{MS}=$ Murashige and Skoog (1962) salts; MS $1 D=$ Murashige and Skoog salts with $1 \mathrm{mg} / 12,4-\mathrm{D}$; MS 2D = Murashige and Skoog salts with $2 \mathrm{mg} / 1$ 2,4-D; $\mathrm{N}_{6}=$ medium of Chu et al. (1975); NN67-mod $=$ medium of Nitsch and Nitsch (1967) as modified in the present paper; $F D A=$ fluorescein diacetate; $L M P=$ low melting point
}

be dense clusters of about $0.1-0.5 \mathrm{~mm}$ in diameter and then stopped growing. Nurse cultures of maize and carrot (Daucus carota L.), were used to establish that individual protoplasts (not contaminating cells or cell clusters) formed walls and divided. Nurse cultures also increased the efficiency of microcallus formation from protoplasts.

Key words: Callus (friable) - Nurse cultures - Protoplast culture - Zea (protoplast cultures).

\section{Introduction}

Protoplasts are essential for genetic engineering experiments such as microinjection, transformation and somatic hybridization. While protoplasts isolated from a number of species have been shown to regenerate fertile plants it has been impossible to induce consecutive divisions in protoplast cultures from many other species such as the cereals. There have been reports of callus formation (Potrykus et al. 1977, 1979; Chourey and Zurawski 1981; Kuang et al. 1983; Deka and Sen 1976; Jones and Dale 1982; Brar et al. 1980) and plantlet formation (Vasil and Vasil 1980; Lu et al. 1981; Heyser 1984) from some cereal protoplast cultures, however these occurred with low efficiency. Whether calli were regenerated from cultured cereal protoplasts or cells or cell clusters has been questioned (Harms 1982; Thomas et al. 1979) because of the high density required $\left(10^{4}\right.$ per $\mathrm{ml}$ or greater $)$ and low frequency (usually 1-5\%) of callus formation.

Here we report on several factors that affect the isolation of maize protoplasts capable of microcallus formation. In addition to using embryogenic callus as the source of protoplasts, we sought to optimize conditions for obtaining high numbers of viable protoplasts during their initial prepara- 
tion and purification. We also sought initial incubation conditions that would maintain high protoplast viability and which induce cell-wall formation and cell divisions. All of these conditions have contributed to the successes reported here in the isolation and initial stages of culture of maize protoplasts.

\section{Materials and methods}

Growth conditions of donor tissue. An embryogenic callus line derived from immature embryos of Zea mays L. (inbred A188) was used as described by Kamo et al. (1985). Media used for embryo culture were either an MS-type medium (Murashige and Skoog 1962) with $2 \%$ sucrose, $0.01 \%$ myoinositol, 1.0 or $2.0 \mathrm{mg} / 1$ 2,4-dichlorophenoxyacetic acid (2,4-D) and modified White's vitamins (White 1954), or an N6 type medium (Chu et al. 1975) with $2 \%$ sucrose, 1.0 or $2.0 \mathrm{mg} / \mathrm{l} 2,4-\mathrm{D}$, and $20 \mathrm{mM}$ proline (Green 1982). Both media had 0.8\% Bacto agar (Difco Laboratories, Detroit, Mich., USA) and were adjusted to $\mathrm{pH}$ 5.8 with $\mathrm{KOH}$. All cultures were incubated in darkness at $26^{\circ} \mathrm{C}$ and transferred to fresh medium every $14 \mathrm{~d}$ unless otherwise noted. This type of callus is referred to as Type I. It is heterogeneous, grows slowly, and looses regeneration capacity after three to six months.

A friable, rapidly growing callus that continued to be embryogenic for at least $9-12$ months was isolated from the compact and highly organized initial (Type I) callus as described by Green (1982) and McNay et al. (1984). The selected callus was transferred weekly and increased two- to four-fold in fresh weight per week. This callus, referred to as Type II, was also used as source tissue for isolation of protoplasts.

Isolation conditions. Several factors were varied in the isolation and purification of protoplasts to optimize yield and viability. The following procedures were routinely followed unless otherwise noted in tables or figures. For protoplast isolation about $1.5 \mathrm{~g}$ of three-week-old Type I callus, grown on MS 1D (Murashige and Skoog with $1 \mathrm{mg} / 1$ 2,4-D), was shaken (40 rpm) for $4 \mathrm{~h}$ in ambient laboratory light at room temperature $\left(21^{\circ} \mathrm{C}\right)$ in $10 \mathrm{ml}$ of a filter-sterilized enzyme mixture (pH 5.9) consisting of $0.2 \%$ Pectolyase Y23 (Seishin Pharmaceutical Co., Tokyo, Japan) and $1 \%$ cellulase (CEL; Cooper Biomedical Cellulase, Malvern, Pa., USA) dissolved in the basal medium described by Nitsch and Nitsch (1967) with various additions. The basal medium contained (in mg/1): $\mathrm{Ca}\left(\mathrm{NO}_{3}\right)_{2} \cdot 4 \mathrm{H}_{2} \mathrm{O}(500), \mathrm{KNO}_{3}$ (125), $\mathrm{MgSO}_{4} \cdot 7 \mathrm{H}_{2} \mathrm{O}(325), \mathrm{KH}_{2} \mathrm{PO}_{4}(125), \mathrm{MnSO}_{4} \cdot \mathrm{H}_{2} \mathrm{O}(25)$, $\mathrm{H}_{3} \mathrm{BO}_{3}(10), \mathrm{ZnSO}_{4} \cdot 7 \mathrm{H}_{2} \mathrm{O}(10), \mathrm{Na}_{2} \mathrm{MoO}_{4} \cdot 2 \mathrm{H}_{2} \mathrm{O}(0.25)$, $\mathrm{CuSO}_{4} \cdot 5 \mathrm{H}_{2} \mathrm{O}(0.025), \mathrm{CoCl}_{2} \cdot 6 \mathrm{H}_{2} \mathrm{O}(0.025)$, Na salt of ethylenediaminotetraacetic acid (EDTA) (7.45), $\mathrm{FeSO}_{4} \cdot 7 \mathrm{H}_{2} \mathrm{O}(5.557)$, glycine (2.0), nicotinic acid (5.0), pyridoxin $\mathrm{HCl}(0.5)$, thiamin $\mathrm{HCl}(0.5)$, biotin (0.05), folic acid (0.05), 2,4-D (2.0), myoinositol (100.0), casein hydrolysate $(200.0)$, and (in $\mathrm{g} / 1)$ : proline (0.7), sucrose (20.0), mannitol (109.2), arabinose (0.125), cellobiose $(0.125)$, fructose $(0.125)$, mannose $(0.125)$, ribose $(0.125)$, xylose $(0.125)$, coconut milk $(20.0 \mathrm{ml} / \mathrm{l})$ and $0.4 \%$ agarose (LMP from Bethesda Research Laboratories, Gaithersburg, Md., USA). Osmolarity of this medium, referred to here as NN67-mod, was measured by freezing-point depression with an Osmette A (Precision Systems, Sudbury, Mass., USA).

Purification procedures. Protoplasts were purified by the procedures of Potrykus et al. (1977) with the following modifications. Protoplasts were filtered through $30-\mu \mathrm{m}$ Nitex cloth (Tetko,
Elmsford, N.Y., USA) and then washed with two volumes of $0.24 \mathrm{M} \mathrm{CaCl}_{2}$ per volume of protoplast suspension. After centrifuging for $15 \mathrm{~min}$ at approx. $50 \cdot \mathrm{g}$, the pellet was resuspended in a mixture of five volumes of $0.54 \mathrm{M}$ sucrose plus one volume NN67-mod and centrifuged for $15 \mathrm{~min}$ at approx. $50 \cdot \mathrm{g}$. Under these conditions, viable protoplasts floated to the top of the solution. They were collected with a Pasteur pipette, filtered through $30-\mu \mathrm{m}$ Nitex cloth, washed in two volumes of $0.24 \mathrm{M}$ $\mathrm{CaCl}_{2}$, and centrifuged at approx. $50 . \mathrm{g}$. The pelleted protoplasts were resuspended in NN67-mod. In the tables and figures dealing with various aspects of the isolation procedure, no standard deviations are given because of the large variation in the number of protoplasts isolated from the same amount of callus from one isolation to the next. However, each experiment was done three times and results are presented only for experiments where the same general trend was observed in each experiment.

Culture methods. Protoplasts were embedded and cultured in a thin layer of agarose $(0.4 \%$ LMP agarose; BRL) on top of $5 \mathrm{ml}$ of already poured and solidified medium in 6 -cm diameter Petri dishes. The cultures were kept in the dark at $26^{\circ} \mathrm{C}$.

Stains. For quantitative estimation of viability, fluorescein diacetate (FDA) staining was used (Widholm 1972). Calcofluor White (Polysciences, Warrington, Pa., USA), a very sensitive stain for cellulose, was used to confirm the removal of cell walls from freshly isolated protoplasts and to monitor the reformation of walls by the plated protoplasts over time (Galbraith 1981). Protoplasts were counted on a hemacytometer.

Cluster formation. Callus formation was quantified by counting the number of clusters containing three or more cells from six random fields per plate for two plates per treatment. All experiments were performed at least three times with two plates per treatment.

Preparation of feeder plates. The "nursed cells" and "feeder cells" refer, respectively, to the cells above and underneath a Nuclepore filter. Plates included either feeder cells or no feeder cells; the latter are designated as "mock-feeder plates". Feeder cells were taken from a fine suspension of carrot (Daucus carota L., selection WOO1C generously provided by R. Sung, University of California, Berkeley, USA) 46 d after transfer to fresh medium, or a maize (A188) suspension (maintained in this laboratory by K. Kamo and T.K. Hodges $4-6 \mathrm{~d}$ after transfer to fresh medium. Feeder cells of both carrot and maize were plated in the same manner and in the same media as the protoplasts. Feeder protoplasts were derived from the same suspension culture of carrot as well as from maize callus cultures following the isolation procedure outlined above. The protoplasts were plated as described before. Sterile Nuclepore filters (Nuclepore Corp., Pleasanton, Cal., USA; size $8 \mu \mathrm{m}$ ) were placed on top of each feeder layer. Aliquots $(5-20 \mu 1)$ of nursed protoplasts suspended in agarose at a density of $10^{2}-10^{4}$ protoplasts $/ \mathrm{ml}$ were placed on top of the filters. The location of individual protoplasts were marked and development of the protoplasts was observed over time.

\section{Results}

Isolation of protoplasts. The isolation and purification techniques described here yielded very clean populations (about $98 \%$ protoplasts and $2 \%$ cells) of uninucleated protoplasts which had a dense cy- 

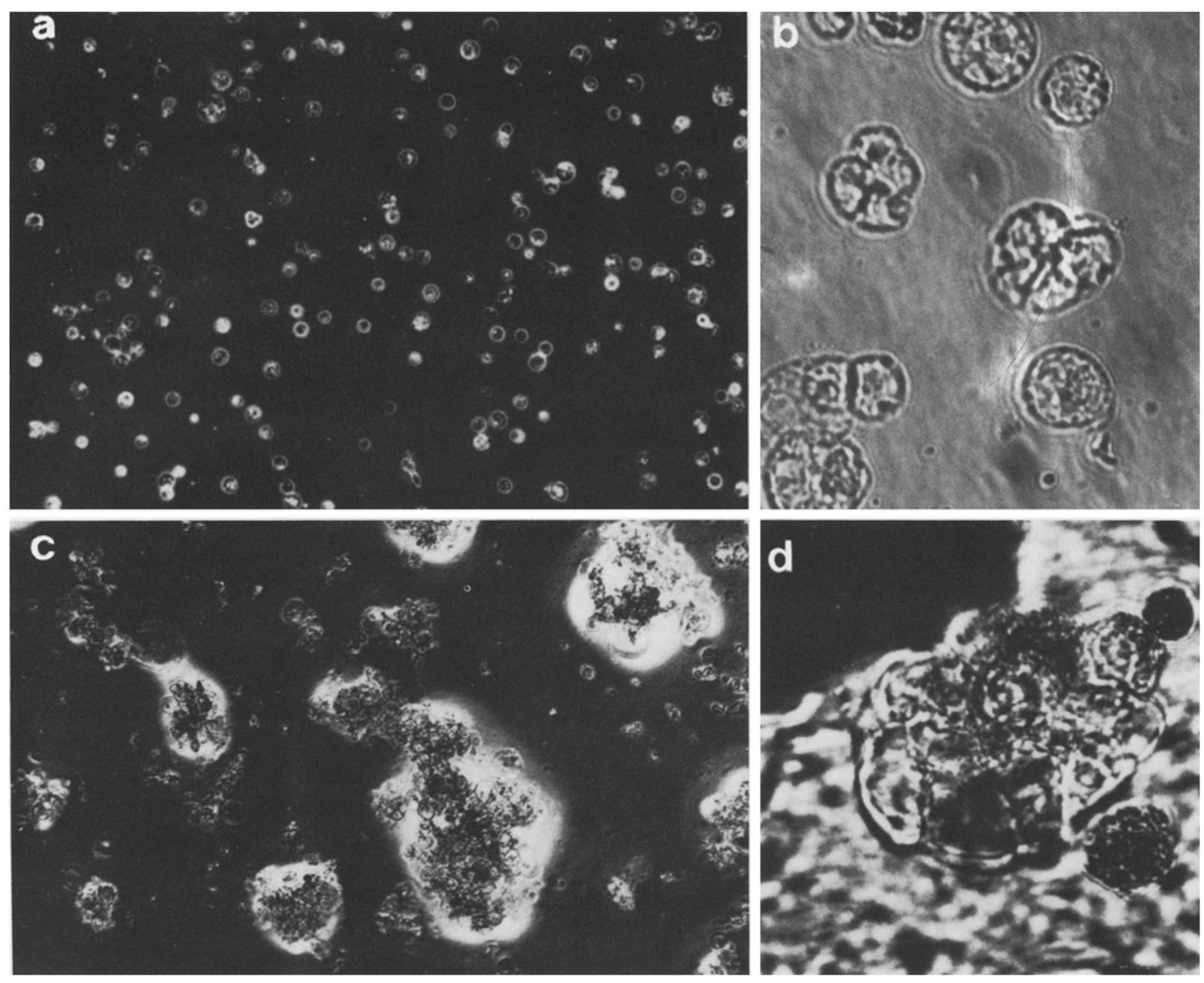

Fig. 1 a-d. Maize protoplasts at various stages of development. a Freshly isolated protoplast $(\times 100)$; b early divisions of protoplasts $5-7 \mathrm{~d}$ after plating in agarose $(\times 100)$; c microcalli formation after one month in agarose $(\times 100)$; d microcallus formation from a single protoplast plated at $10^{2}$ protoplasts $/ \mathrm{ml}$ in a $20-\mu 1$ drop on a nurse culture of carrot suspension cultures $(\times 400)$

toplasm and varied in size from 20 to $50 \mu \mathrm{m}$ in diameter (Fig. 1). Staining with Calcofluor White indicated that the walls of the cells were completely removed after a 4 -h enzyme incubation. Over $80 \%$ of the protoplasts were viable as measured with FDA. By the isolation, purification, and culture conditions described above, microcalli could be obtained from $25 \%$ of the protoplasts plated. The use of nurse cultures of corn or carrot protoplasts or suspension cultures has allowed us to substantiate that protoplasts (not contaminating cells or cell clusters) can re-form walls and undergo a series of divisions.

Growth conditions of donor tissue. Growth conditions of the callus cultures were found to be very important for obtaining protoplasts capable of regenerating cell walls and initiating cell divisions. There was a significantly higher yield and viability of protoplasts obtained from callus (Type I) grown on MS (1D or 2D) medium than on N6 (1D or 2D) (Table 1). In both media, the lower concentration of 2,4-D gave higher yields and viability. No improvement in either protoplast yield or viability was found by substituting $\mathrm{NH}_{4}^{+}$(added as $\left.\left(\mathrm{NH}_{4}\right)_{2} \mathrm{SO}_{4}\right), \mathrm{NO}_{3}^{-}$(added as $\mathrm{KNO}_{3}$ ) or glutamine as the sole nitrogen source in MS medium during the growth of the Type I callus (data not shown). For the friable callus (Type II), growth on MS medium also produced callus that gave higher yields of protoplasts than callus grown on N6 medium. However, in contrast to the Type I callus, Type II friable callus grown on MS 2D gave higher protoplast yields than callus grown on MS 1D (Table 1).

While more protoplasts were isolated from older Type I callus (four or six weeks in culture) on a per-embryo basis, a higher number of viable protoplasts was isolated from immature embryos in 
Table 1. Protoplasts isolated from two types of maize callus grown on MS or N6 media at two concentrations of 2,4-D. Immature embryos were initially plated on the appropriate medium, transferred to new medium at two weeks, and used at three weeks for the Type I callus. The Type II callus was subcultured weekly for at least one month in the appropriate medium before it was used for protoplast isolation. Protoplasts were counted immediately after the $4-h$ incubation in enzyme, i.e. before any further purification

\begin{tabular}{llllll}
\hline Media & \multicolumn{2}{l}{ Callus type } & & \\
\cline { 2 - 3 } & I & & II & \\
\cline { 2 - 3 } \cline { 5 - 6 } & $\begin{array}{l}\text { Proto- } \\
\text { plasts } \\
\text { (No./g) }\end{array}$ & $\begin{array}{l}\text { Via- } \\
\text { bility } \\
(\%)\end{array}$ & & $\begin{array}{l}\text { Proto- } \\
\text { plasts } \\
\text { (No./g) }\end{array}$ & $\begin{array}{l}\text { Via- } \\
\text { bility } \\
(\%)\end{array}$ \\
\hline MS 1D & $28.3 \cdot 10^{6}$ & 83 & & $0.11 \cdot 10^{6}$ & 90 \\
MS 2D & $22.1 \cdot 10^{6}$ & 50 & $0.29 \cdot 10^{6}$ & 88 \\
N6 1D & $4.5 \cdot 10^{6}$ & 29 & $0.08 \cdot 10^{6}$ & 74 \\
N6 2D & $2.5 \cdot 10^{6}$ & 17 & $0.03 \cdot 10^{6}$ & 64 \\
\hline
\end{tabular}

culture for only two to three weeks (data not shown). The type of callus (Type I or II) affected protoplast yield but not viability (Table 1). As will be shown later, isolation conditions could be modified to increase the yield of protoplasts from the Type II callus.

Isolation solutions. The type of enzymes and their concentrations affected the number of viable protoplasts. Of the cellulases tested, the Cooper Biomedical cellulase (CEL) used at $1 \%$ gave the highest yield of viable protoplasts (Table 2). The type of enzymes used to isolate protoplasts also affected the number of clusters formed from plated protoplasts. Pectolyase Y23 plus and minus Macerozyme R-10 (Yakult Pharmaceutical Industry Co., Nishinomiya, Japan) gave the same yield $\left(2.4 \cdot 10^{6}\right.$ protoplasts $/ \mathrm{ml}$ with Pectolyase Y23 only and $2.5 \cdot 10^{6}$ protoplasts $/ \mathrm{ml}$ with both pectinases). Also, Pectolyase Y23 gave about the same yield of viable protoplasts at $0.2 \%\left(2.24 \cdot 10^{6}\right.$ protoplasts $\left./ \mathrm{ml}\right)$ and $0.5 \%\left(2.23 \cdot 10^{6}\right.$ protoplasts $\left./ \mathrm{ml}\right)$.

The osmolarity of the enzyme incubation medium had a substantial effect on the yield and viability of the protoplasts. The distinct optimum in osmolarity of the enzyme incubation medium was at about 780 mosmol using $0.6 \mathrm{M}$ mannitol as the osmoticum (Table 3 ). The $\mathrm{pH}$ of the enzyme incubation medium affected both protoplast yield and viability. While the highest total yield of protoplasts was at $\mathrm{pH} 7.0$, the highest number of viable protoplasts was obtained at $\mathrm{pH} 6.0$ (Fig. 2). Although polyamines have been shown to stabilize oat leaf protoplasts (Altman et al. 1977), the addi-
Table 2. Effect of different cellulases on protoplast yield and viability from Type I callus of maize. For each treatment 1.4-1.6 $\mathrm{g}$ of callus grown on MS $1 \mathrm{D}$ was added to $10 \mathrm{ml}$ enzyme incubation medium. Total protoplasts were resuspended in $2.0 \mathrm{ml}$ of medium. R10 and RS cellulases were obtained from Yakult Pharmaceutical Industry Co., Nishinomiya, Japan. CEL refers to cellulase obtained from Cooper Biomedical, Scientific Division, Malvern, Pa., USA

\begin{tabular}{lllll}
\hline $\begin{array}{l}\text { Cellu- } \\
\text { lase }\end{array}$ & $\begin{array}{l}\text { Concn. } \\
(\%)\end{array}$ & $\begin{array}{l}\text { Protoplasts } \\
(\text { No./ml) }\end{array}$ & $\begin{array}{l}\text { Viable } \\
\text { protoplasts } \\
\text { (No./ml) }\end{array}$ & $\begin{array}{l}\text { No. } \\
\text { clusters/ } \\
\text { field }^{\mathrm{a}}\end{array}$ \\
\hline R10 & 0.50 & $1.04 \cdot 10^{6}$ & $0.97 \cdot 10^{6}(93)^{\mathrm{b}}$ & $11.7 \pm 4.0^{\mathrm{c}}$ \\
& 1.00 & $0.92 \cdot 10^{6}$ & $0.86 \cdot 10^{6}(94)$ & $12.0 \pm 3.9$ \\
& 2.00 & $0.30 \cdot 10^{6}$ & $0.28 \cdot 10^{6}(95)$ & $9.3 \pm 2.6$ \\
RS & 0.25 & $0.28 \cdot 10^{6}$ & $0.26 \cdot 10^{6}(94)$ & $5.6 \pm 1.4$ \\
& 0.50 & $0.50 \cdot 10^{6}$ & $0.44 \cdot 10^{6}(88)$ & $4.0 \pm 2.0$ \\
CEL & 1.00 & $0.78 \cdot 10^{6}$ & $0.74 \cdot 10^{6}(96)$ & $2.1 \pm 1.7$ \\
& 0.25 & $2.33 \cdot 10^{6}$ & $2.10 \cdot 10^{6}(93)$ & $34.3 \pm 8.1$ \\
& 0.50 & $4.00 \cdot 10^{6}$ & $3.76 \cdot 10^{6}(94)$ & $32.8 \pm 4.3$ \\
& 1.00 & $7.2 \cdot 10^{6}$ & $6.34 \cdot 10^{6}(94)$ & $35.6 \pm 6.2$ \\
\hline
\end{tabular}

a Measured after four weeks in culture

b Numbers in parentheses are percentages

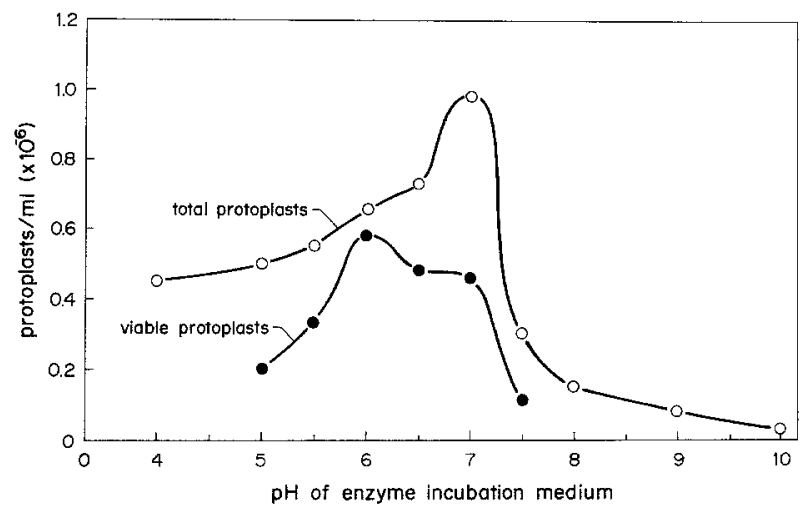

Fig. 2. The effect of $\mathrm{pH}$ on maize protoplast yield and viability was tested by adjusting the $\mathrm{pH}$ of the enzyme incubation medium over a range from 4 to $10 . \mathrm{pH}$ was adjusted using $\mathrm{KOH}$ or $\mathrm{HCl}$. For each treatment $1.4-1.6 \mathrm{~g}$ of callus was added to $10 \mathrm{ml}$ of the enzyme incubation medium. Total protoplasts were resuspended in $3.5 \mathrm{ml}$ of medium at the appropriate $\mathrm{pH}$

tion of polyamines (putrescine at $1 \mathrm{mM}$, cadaverine at $10 \mathrm{mM}$, spermine at $1 \mathrm{mM}$, and spermidine at $1 \mathrm{mM}$ ) had no significant effect on either yield or viability of corn protoplasts from Type I callus. Spermine, however, increased the number of viable protoplasts isolated from Type II callus (from $1.67 \cdot 10^{6}$ to $4.35 \cdot 10^{6}$ protoplasts $/ \mathrm{ml}$ ), making it comparable to the number of protoplasts derived from Type I callus $\left(4.35 \cdot 10^{6}\right.$ protoplasts $\left./ \mathrm{ml}\right)$.

Isolation conditions. Pre-plasmolysis had no effect on either protoplast yield or viability (data not shown). Gentle shaking (40 rpm) gave the highest 
Table 3. Effect of osmolarity of the enzyme incubation medium on maize protoplast yield and viability. For each treatment 1.3-1.5 $\mathrm{g}$ of callus grown on MS 1D was added to $10 \mathrm{ml}$ enzyme incubation medium. Total protoplasts were resuspended in $1.5 \mathrm{ml}$ of medium

\begin{tabular}{|c|c|c|c|}
\hline Osmoticum & mosmol & $\begin{array}{l}\text { Protoplasts } \\
\text { (No./ml) }\end{array}$ & $\begin{array}{l}\text { Viable } \\
\text { protoplasts } \\
\text { (No./ml) }\end{array}$ \\
\hline 0.3 M Mannitol & 421 & $2.3 \cdot 10^{6}$ & $(0)^{a}$ \\
\hline $0.4 \mathrm{M}$ Mannitol & 538 & $1.9 \cdot 10^{6}$ & $0.1 \cdot 10^{6} \quad(6)$ \\
\hline $0.6 \mathrm{M}$ Mannitol & 777 & $7.9 \cdot 10^{6}$ & $6.8 \cdot 10^{6}(86)$ \\
\hline $0.8 \mathrm{M}$ Mannitol & 1003 & $1.4 \cdot 10^{6}$ & $1.3 \cdot 10^{6}(92)$ \\
\hline 1.0 M Mannitol & 1237 & $0.7 \cdot 10^{6}$ & $0.6 \cdot 10^{6}(91)$ \\
\hline $\begin{array}{l}0.2 \mathrm{M} \text { Mannitol } \\
\quad+80 \mathrm{mM} \mathrm{CaCl}_{2}\end{array}$ & 509 & $6.4 \cdot 10^{6}$ & $3.4 \cdot 10^{6}(54)$ \\
\hline
\end{tabular}

- Numbers in parentheses are percentages

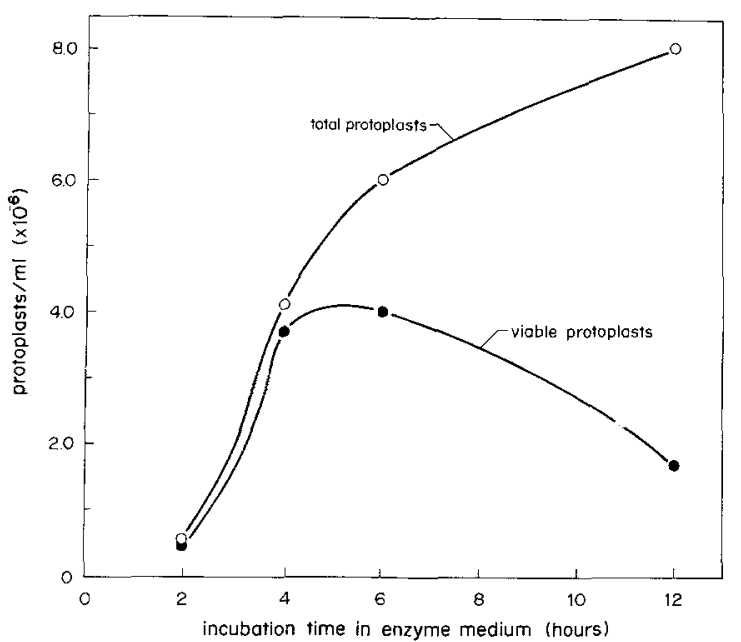

Fig. 3. Effect of time in enzyme incubation medium on yield of total and viable protoplasts from Type I callus of maize. Protoplasts were isolated by the standard isolation procedures outlined in Materials and methods. For each treatment, $1.5-1.7 \mathrm{~g}$ of callus was added to $10 \mathrm{ml}$ of the enzyme incubation medium. Total protoplasts were resuspended in $2.5 \mathrm{ml}$ of medium

yield of viable protoplasts whereas shaking at $140 \mathrm{rpm}$ decreased the number of viable protoplasts isolated by $26 \%$ (data not shown). Although 12-h incubations in enzyme medium gave the highest yield of protoplasts, 4- to 6-h incubations gave higher yields of viable protoplasts (Fig. 3). The weight of callus incubated in $10 \mathrm{ml}$ of the enzyme incubation medium affected both the total number of protoplasts and the number of viable protoplasts isolated (Fig. 4). For callus Type I, the greatest number of viable protoplasts was obtained from $1.5 \mathrm{~g}$ callus per $10 \mathrm{ml}$ of enzyme incubation solution. However, for callus Type II, the peak was at a considerably higher weight of callus $(5.0 \mathrm{~g}$ of

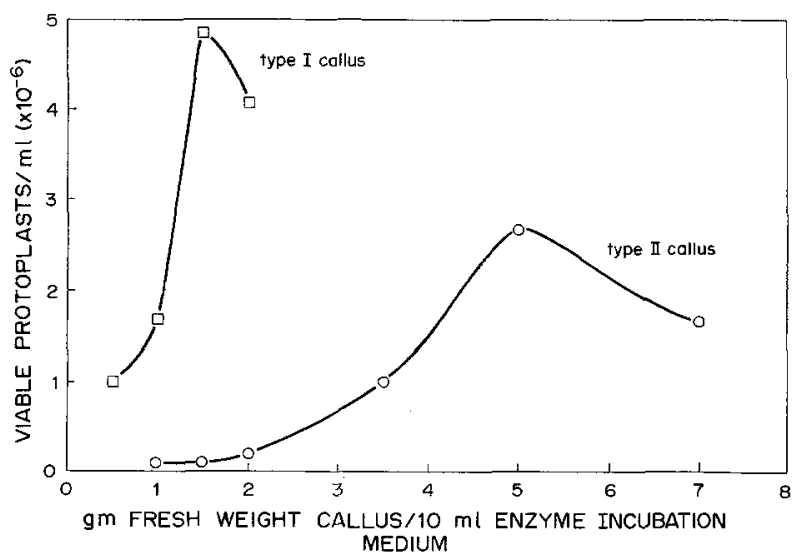

Fig. 4. Number of viable protoplasts produced as a function of amount of maize callus (Type I or Type II) per $10 \mathrm{ml}$ of enzyme incubation medium. Type I callus was grown on MS 1D-type medium and Type II callus was grown on MS 2D-type medium. Total protoplasts were resuspended in $2.5 \mathrm{ml}$ medium

friable callus per $10 \mathrm{ml}$ enzyme incubation medium).

Protoplast culture. Protoplasts plated in NN67mod embedded in $0.4 \%$ agarose over thin layers of solidified medium formed walls and divided to form microcalli (Fig. 1). The type of agarose affected the number of clusters of cells that eventually developed (Table 4). With the low-melting-point agaroses, the protoplasts were plated at $37^{\circ} \mathrm{C}$. The higher temperature $\left(45^{\circ} \mathrm{C}\right)$ necessary to keep agar liquid did not prevent the formation of clusters when using the LMP agarose. However, protoplasts plated in the same way but embedded in agar (plated at $45^{\circ} \mathrm{C}$ for a final concentration of $0.8 \%$ ) formed walls but did not divide.

Protoplasts were plated over a wide range of densities from $10^{4}$ to $10^{7}$ protoplasts $/ \mathrm{ml}$. The plating efficiency as a function of protoplast density is shown in Fig. 5. The highest efficiency (25\%) was found at about $1 \cdot 10^{6}$ protoplast $/ \mathrm{ml}$.

Microcallus fate. The microcalli obtained were composed of dense clusters with about 50 . 200 cells. The clusters ranged in size from 0.1 to $0.5 \mathrm{~mm}$ in diameter after one month in culture. While the clusters remained viable (based on staining with FDA) for at least three months, they did not continue to grow. Since the cell cultures ceased to grow after four to six weeks no attempt has been made to initiate morphogenesis or regeneration.

Maize protoplasts $\left(10^{2}-10^{3}\right.$ protoplasts $\left./ \mathrm{ml}\right)$ embedded in agarose and plated in drops on a Nuclepore filter over mock feeder plates contain- 


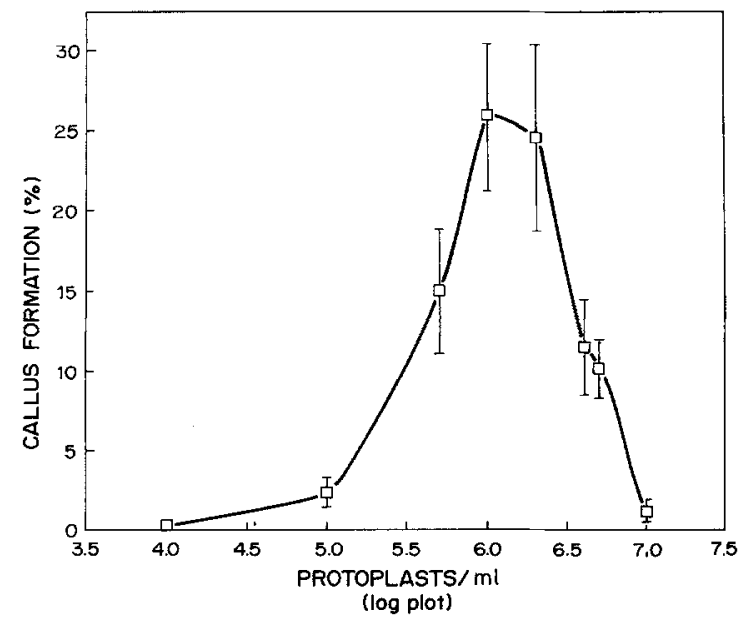

Fig. 5. Plating efficiency of maize protoplasts (number of microcalli/number of protoplasts $\times 100$ ) versus density of the cultured protoplasts in NN67-mod medium

Table 4. Effect of various agaroses and agar for initiating cell divisions in protoplast cultures obtained from Type I maize callus grown on MS 1D

\begin{tabular}{lllll}
\hline $\begin{array}{l}\text { Gelling } \\
\text { agent }\end{array}$ & Source & $\begin{array}{l}\text { Temper- Concn. } \\
\text { ature for } \\
\text { plating }\end{array}$ & $\begin{array}{l}\text { Protoplast } \\
\text { development } \\
\text { (No. clusters/ } \\
\text { field) }\end{array}$ \\
\hline SeaPlaqueLMT & FMC & 37 & 0.7 & $21.3 \pm 2.3^{\mathrm{b}}$ \\
Type VII & Sigma & 37 & 0.4 & $28.3 \pm 4.2$ \\
LMP Agarose & BRL & 37 & 0.4 & $45.6 \pm 7.6$ \\
LMP Agarose & BRL & 45 & 0.4 & $32.0 \pm 5.0$ \\
Bacto Agar & Difco & 45 & 0.8 & 0 \\
\hline
\end{tabular}

a $\mathrm{FMC}=\mathrm{FMC}$ BioProducts, Rockland, Me., USA; Sigma = Sigma Chemical Co., St. Louis, Mo., USA; BRL=Bethesda Research Laboratories, Gaithersburg, Mod., USA; Difco= Difco Laboratories, Detroit, Mich., USA

b Numbers are the mean $\pm S D$

ing a layer of NN67-mod with $0.4 \%$ agarose did not form walls or divide. Of 20 individual maize protoplasts plated on a Nuclepore filter over a feeder layer of maize protoplasts plated at a density of $10^{6}$ protoplasts $/ \mathrm{ml}$, three nursed protoplasts divided at least twice. With maize suspension culture cells and cell clusters as the feeder layer, five out of 20 nursed protoplasts divided. Of 20 individual protoplasts plated over a feeder layer of carrot cells, six divided several times (Fig. 1 d). It was very difficult to follow individual protoplasts plated over feeder layers of carrot protoplasts. However, when the Nuclepore filter was removed from the feeder layer, approx. $40 \%$ of the protoplasts gave rise to clusters of cells.

\section{Discussion}

In the present study, we were able to obtain conditions for the formation of microcalli from maize protoplasts. This was done with two types of embryogenic callus obtained from immature embryos of the inbred line A188. Protoplasts of only two other lines of maize, Black Mexican Sweet (Chourey and Zurawski 1981) and B73 (Potrykus et al. 1977), have been reported to be capable of wall formation and cell divisions. In neither case was the initial callus capable of plant regeneration; thus the lack of regeneration from the protoplast cultures was not surprising. In our study, we did not achieve regeneration of plants from the protoplast-derived calli, either. Nevertheless, we are optimistic that this will be possible because the starting material, i.e. Types I and II callus from immature embryos, was embryogenic and thus contained totipotent cells (Kamo et al. 1985).

Our isolation procedure, with the optimization of several factors, gave a high yield (greater than $10^{6}$ protoplasts per gram tissue) of viable protoplasts. However, not all viable protoplasts had the same potential to re-form a cell wall and divide. Although $88 \%$ or more of the protoplasts isolated with various concentrations of R10, RS, and CEL cellulases were viable, there was a significant difference in the number of cell clusters formed from those protoplasts after plating (Table 2).

Of the several options for culturing available, only plating in agarose resulted in consistent growth and development of maize protoplasts. When protoplasts were cultured either in liquid medium on microtiter plates or in an emulsion of $2 \mathrm{ml}$ liquid and 5-10 $\mathrm{ml}$ paraffin oil (Fisher 0-119, Saybolt viscosity $125 / 135$ ) mixed at a vortex setting of 5 for 3-5 s (according to David Galbraith, University of Nebraska, Lincoln, NE, USA; personal communication), $30-40 \%$ of the protoplasts remained viable (as assessed with FDA). However, these protoplasts did not form walls or divide. Microcalli formed from $25 \%$ of the protoplasts plated only when embedded in agarose (Fig. 5). Agarose has been shown to be an excellent gelling agent for the culture of other plant protoplasts (Shillito et al. 1983). The use of a complex medium including cell-wall sugar precursors (Fitter and Krikorian 1981) as well as the use of LMP agarose (Table 5; see also Shillito et al. 1983) also stimulated the formation of callus from protoplasts. The use of specific sugar precursors are currently under investigation.

The use of nurse cultures (Horsch and Jones 1980; Hein et al. 1983; Shneyour et al. 1983) has 
enabled us to identity unequivocally individual maize protoplasts forming walls and dividing. Further, we have shown that protoplasts as well as cells from both the same species and a distantly related species (carrot) can support the growth and development of maize protoplasts plated at low densities. The frequency of callus formation was in fact highest with the nurse cultures.

Studies are now in progress for optimization of the culture conditions necessary for the continued growth of the protoplast-derived microcalli.

This research was supported by Agrigenetics Associates, Boulder, Colo., USA. Published as Journal Paper 10,437 of the Purdue University Agricultural Experiment Station.

\section{References}

Altman, A., Kaur-Sawhney, R., Galston, A.W. (1977) Stabilization of oat leaf protoplasts through polyamine-mediated inhibition of senescence. Plant Physiol. 60, 570-574

Brar, D.S., Rambold, S., Constabel, F., Gamborg, O.L. (1980) Tissue culture of corn and sorghum. Z. Pflanzenphysiol. 96, 269-275

Chourey, P.S., Zurawski, D.B. (1981) Callus formation from protoplasts of a maize cell cultures. Theor. Appl. Genet. 59, 344-349

Chu, C.C., Wang, C.C., Sun, C.S., Hsu, C. Yin, K.C., Chu, C.Y. (1975) Establishment of an efficient medium for anther culture of rice through comparative experiments on the nitrogen sources. Sci. Sinica 18, 659-668

Deka, P.C., Sen, S.K. (1976) Differentiation in calli originated from isolated protoplasts of rice (Oryza sativa L.) through plating technique. Mol. Gen. Genet. 145, 239-243

Fitter, M.S., Krikorian, A.D. (1981) Recovery of totipotent cells and plantlet production from day lily protoplasts. Ann. Bot. 48, 591-597

Galbraith, D.W. (1981) Microfluorimetric quantitation of cellulose biosynthesis by plant protoplasts using Calcofluor White. Physiol. Plant. 53, 111-116

Green, C.E. (1982) Somatic embryogenesis and plant regeneration from the friable callus of Zea mays. In: Plant tissue culture (Proc. V Int. Congr. Plant Tissue and Cell Culture) pp. 107-108, A. Fujiwara, A., ed. Abe Photo Printing, Tokyo

Harms, C.T., (1982) Maize and cereal protoplasts - facts and perspectives. In: Maize for biological research, pp. 373-384, Sheridan, W.F., ed. University of North Dakota Press, Grand Forks, USA

Hein, T., Przewozny, T., Schieder, O. (1983) Culture and selection of somatic hybrids using an auxotrophic cell line. Theor. Appl. Genet. 64, 119-122
Heyser, J.W. (1984) Callus and shoot regeneration from protoplasts of proso millet (Panicum miliaceum L.). Z. Pflanzenphysiol. 113, 293-299

Horsch, R.B., Jones, G.E. (1980) A double filter technique for plating cultured plant cells. In Vitro 16, 103-108

Jones, M.G.K., Dale, P.J. (1982) Reproducible regeneration of callus from suspension culture protoplasts of the grass Lolium multiflorum. Z. Pflanzenphysiol. 105, 267-274

Kamo, K.K., Becwar, M.R., Hodges, T.K. (1985) Regeneration of Zea mays L. from embryogenic callus. Bot. Gaz. 146, 327-334

Kuang, V.D., Shamina, Z.B., Butenko, R.G. (1983) Use of nurse tissue culture to obtain clones from cultured cells and protoplasts of corn. Soviet Plant Physiol. 30, 613-620

Lu, C.-Y., Vasil, V., Vasil, I.K. (1981) Isolation and culture of protoplasts of Panicum maximum Jacq. (Guinea grass): Somatic embryogenesis and plantlet formation. Z. Pflanzenphysiol. 104, 311-318

McNay, J.W., Chourey, P.S., Pring, D.R. (1984) Molecular analysis of genomic stability of mitochondrial DNA in tissue culture of maize. Theor. Appl. Genet. 6, 433-437

Murashige, T., Skoog, F. (1962) A revised medium for rapid growth and bioassays with tobacco tissue cultures. Physiol. Plant. 15, 473 497

Nitsch, C., Nitsch, J.P. (1967) The induction of flowering in vitro in stem segments of Plumbago indica L. II. The production of reproductive buds. Planta 72, 355-370

Potrykus, I., Harms, C.T., Lorz, H. (1979) Callus formation from cell culture protoplasts of corn (Zea mays L.). Theor. Appl. Genet. 54, 209-214

Potrykus, I., Harms, C.T., Lorz, H., Thomas, E. (1977) Callus formation from stem protoplasts of corn (Zea mays L.) Mol. Gen. Genet. 156, 347-350

Shillito, R.D., Paszkowski, J., Potrykus, I. (1983) Agarose plating and a bead type culture technique enable and stimulate development of protoplast-derived colonies in a number of plant species. Plant Cell Rep. 2, 244-247

Shneyour, Y., Zelcher, A., Uzhar, S., Beckman, J.S. (1984) A simple feeder-layer technique for the plating of plant cells and protoplasts at low density. Plant Sci. Lett. 33, 293-302

Thomas, E., King, P.J., Potrykus, I. (1979) Improvement of crop plants via single cells in vitro: an assessment. Z. Pflanzenphysiol. 82, 1-30

Vasil, V., Vasil, I.K. (1980) Isolation and culture of cereal protoplasts. II. Embryogenesis and plantlet formation from Pennisetum americanum. Theor. Appl. Genet. 56, 97-99

White, P.R. (1954) The cultivation of animal and plant cells Ronald Press, New York

Widholm, J.M. (1972) The use of fluorescein diacetate and phenosafranine for determining viability of cultured plant cells. Stain Technol. 47, 189-194

Received 2 January; accepted 2 April 1986 